\title{
Comparative analysis of surgical treatments of non-union in forearm fractures
}

\author{
I.Yu. Khodjanov' ${ }^{1}$ A.M. Rakhimov ${ }^{1}$, A.A. Kosimov ${ }^{2,3}$ \\ ${ }^{1}$ Republican Specialized Scientific-practical Medial Centre of Traumatology and Orthopaedics, Tashkent, the Republic of Uzbekistan \\ ${ }^{2}$ Tashkent Medical Academy, Tashkent, Uzbekistan \\ ${ }^{3}$ Tashkent state dental medical Institute, Tashkent, Uzbekistan
}

\begin{abstract}
Objective TObjective To compare outcomes of non-union in forearm fractures treated with the use of a comprehensive surgical approach considering the injury pattern and localization. Material and methods Based on treatment approaches the cases were categorized into 3 groups with proximal forearm fractures (group I, $\mathrm{n}=28 ; 33.8 \%$ ), mid-shaft and distal forearm fractures (group II, $\mathrm{n}=32 ; 38.5 \%$ ), and controls (group III, $\mathrm{n}=23 ; 27.7 \%$ ). Group I included patients with hypertrophic nonunion (HTNU) of the forearm bones treated with bone graft and plating. Group II consisted of atrophic nonunion, HTNU of the forearm bones repaired with the Ilizarov external fixation. A single $3 \mathrm{~mL}$ local injection of autologous bone marrow and a kukumazim solution of 50 PU were used to induce bone fusion in the patients of the two groups. The control group included non-unions with no considerations to the fracture pattern and localization. All patients underwent physical, radiological examinations and laboratory tests. Results The control group showed $8.7 \%$ poor and $69.5 \%$ good outcomes at a long term, whereas $3.6 \%$ results were rated as poor and $82.1 \%$ as good in group I, with $3.1 \%$ poor and $87.6 \%$ good outcomes in group II. The ratings can be associated with a differentiated surgical approach considering the injury pattern and localization, the use of kukumazim proteolytic enzymes and autologous bone marrow injection. Conclusion Optimization of surgical treatments and considerations for injury pattern and localization allowed for a 2.8 -time $(3.1 \%)$ decrease in poor outcomes and a $30 \%$ reduction in the limb immobilization period.
\end{abstract}

Keywords: non-union, atrophic, hypertrophic, forearm bones

\section{BACKGROUND}

Forearm nonunions remain a common severe complication of ulna and radius fractures and account for $20-25 \%$ of all nonunions of long bones in the practice of reconstructive surgery [1-5]. The forearm is a complex anatomic structure and a very important part of the upper extremity with two unidimensional bones, muscles and neurovascular bundles being located close to each other. With one of the forearm bones broken, the other acts as a strut. Fractured ulna and radius normally results in significant bone displacement and pronounced forearm bone deformaties due to the multidirectional muscles' traction. This leads to repeated bone reduction, traumatic surgical interventions and requires rigid fixation of the fracture site to rule out any muscle activity in achieving timely osteoregeneration. Neurovascular bundles running along the bones and pronounced neurocirculatory disorders contribute to the development of various complications [2, 3, 6-8]. Forearm nonunions are associated with pathologic bone and soft tissues that are difficult to treat. Literature review indicates to the lack of a comprehensive approach [1,7-19] to the surgical treatment of atrophic or hypertrophic forearm nonunions taking into considerations fracture location, and low effectiveness of the available osteostimulation techniques, the high rate of poor outcomes led to the search for differentiated surgical methods combined with osteostimulation and the use of effective and safe proteolytic enzyme preparations. Multiple factors have been associated with the establishment of forearm nonunions such as fracture location and complexity, patient characteristics and surgical technique. Despite numerous studies performed in different countries, forearm nonunions are severely disabling among people of working age, in particular.

Objective To compare outcomes of non-union in forearm fractures treated with the use of a comprehensive surgical approach considering the injury pattern and localization.

\section{MATERIAL AND METHODS}

The study included 83 participants with 29 (34.9\%) female and 54 male patients $(65.1 \%)$ treated at adult trauma department of the Republican Specialized Medical Center for Trauma and Orthopaedics between 2009 and 2017. The patients' age ranged from 18 to 82 years with the mean of $34.2 \pm 1.3$ years. Based on treatment approaches the cases were categorized into 3 groups with proximal forearm fractures. Group I $(\mathrm{n}=28 ; \quad 33.8 \%)$ included nonunited fractures $(\mathrm{n}=3)$ and nonunions treated after 2012. No Ilizarov external fixation was performed for the patients with the injury located in the upper third of the forearm. 
Group II $(\mathrm{n}=32 ; 38.5 \%)$ consisted of patients with mid-shaft and distal forearm fractures followed up after 2012. The group included nonunited fractures $(n=3)$ and nonunions $(n=29)$. Patients of group II with atrophic nonunion $(n=19)$ were treated with osteotomy performed over the nonunion level to create environment for distractional regeneration with the Ilizarov external fixation and autologous bone marrow and a kukumazim solution additionally injected. Hypertrophic nonunion $(\mathrm{n}=10)$ and nonunited forearm fractures $(n=3)$ were treated with the Ilizarov external fixation and autologous bone marrow and a kukumazim solution was additionally injected. In addition to surgical repair of the forearm fractures patients of the two groups were additionally treated with kukumazim locally injected in the injury site and autologous bone marrow harvested from the patient's cancellous bone injected locally in the pathological area. The findings of the two main groups were compared with those of control (retrospective group) patients $(\mathrm{n}=23 ; 27.7 \%)$ with nonunited forearm fracture $(\mathrm{n}=5)$ and forearm nonunion $(\mathrm{n}=18)$ treated between 2009 and 2012.

Table 1 shows the distribution of patients with regard to the bone injured (ulna, radius, both bones), the fracture location (the upper third ( $\mathrm{n}=18$, middle third $(n=36)$ and the lower third $(n=29)$ and the type (hypertrophic nonunion (HNU), atrophic nonunion (ANU) and nonunited fractures). Table 1 demonstrates the ulna as the more commonly injured segment $(\mathrm{n}=33)$, the radius was broken in 21 patients, and injury to both forearm bones occurred in 27 patients. The fracture location included the mid shaft $(\mathrm{n}=36)$, proximal forearm bone $(\mathrm{n}=18)$ and distal forearm $(\mathrm{n}=29)$. Nonunions were classified as hypertrophic $(n=35)$ and atrophic $(n=39)$. Fractures failed to heal in the rest 9 cases. Atrophic nonunion was mainly seen in the mid shaft due to the anatomical features of the forearm bones and the blood supply. The fracture location played a role in the choice of treatment strategy, which will be discussed below.

Table 2 shows the distribution of the patients by the type of nonunion and the surgical approach used. Controls underwent closed Ilizarov application $(\mathrm{n}=16$; $19.3 \%)$, open intramedullary wiring $(n=6 ; 7.2 \%)$ and plating and bone grafting with the Khakhutov method $(n=1)$. Patients of group I $(n=21 ; 25.3 \%)$ underwent autologous bone grafting and plating, and bone grafting with the Khakhutov method and plating $(\mathrm{n}=7 ; 8.4 \%)$ (Table 2). 13 (15.7\%) patients of group II with HNU $(\mathrm{n}=10)$ and nonunited forearm fracture $(n=3)$ were treated with the Ilizarov external fuxation and kukumazim and autologous bone marrow locally injected in the injury site. ANU $(n=19 ; 22.9 \%)$ was repaired with the Ilizarov frame, bone osteotomy and local injection of kukumazim and autologous bone marrow (Table 2). Physical, laboratory and radiological examinations were performed for all patients.

Table 1

Distribution of patients with nonunited forearm fractures and nonunions by the type of injury and location $(\mathrm{n}=83)$

\begin{tabular}{|c|c|c|c|c|c|c|c|}
\hline Location & Bone & Type of injury & Control group $(n=23)$ & Group I $(n=28)$ & Group II $(n=32)$ & \multicolumn{2}{|c|}{ Total } \\
\hline \multirow{8}{*}{$\begin{array}{l}\text { Proximal } \\
\text { forearm bones }\end{array}$} & \multirow{2}{*}{ Radius } & $\mathrm{HNU}$ & - & - & - & - & \multirow{8}{*}{18} \\
\hline & & ANU & - & - & - & - & \\
\hline & \multirow{3}{*}{ Ulna } & $\mathrm{HNU}$ & 2 & 3 & - & 7 & \\
\hline & & ANU & - & 4 & 1 & 5 & \\
\hline & & Nonunited fracture & 2 & 2 & 1 & 3 & \\
\hline & \multirow{3}{*}{ Radius and ulna } & HNU & - & - & 1 & 1 & \\
\hline & & ANU & 1 & - & - & 1 & \\
\hline & & Nonunited fracture & 1 & - & - & 1 & \\
\hline \multirow{8}{*}{$\begin{array}{l}\text { Mid shaft of the } \\
\text { forearm bones }\end{array}$} & \multirow{2}{*}{ Radius } & $\mathrm{HNU}$ & - & 2 & 2 & 4 & \multirow{8}{*}{36} \\
\hline & & ANU & - & 1 & - & 1 & \\
\hline & \multirow{3}{*}{ Ulna } & $\mathrm{HNU}$ & - & - & 2 & 2 & \\
\hline & & ANU & 4 & 3 & 5 & 12 & \\
\hline & & Nonunited fracture & - & - & 1 & 1 & \\
\hline & \multirow{3}{*}{ Radius and ulna } & HNU & 4 & 3 & - & 7 & \\
\hline & & ANU & 1 & - & 7 & 8 & \\
\hline & & Nonunited fracture & 1 & - & & 1 & \\
\hline \multirow{8}{*}{$\begin{array}{l}\text { Distal forearm } \\
\text { bones }\end{array}$} & \multirow{3}{*}{ Radius } & $\mathrm{HNU}$ & 1 & 2 & 5 & 8 & \multirow{8}{*}{29} \\
\hline & & ANU & 1 & 4 & 3 & 8 & \\
\hline & & Nonunited fracture & - & 1 & 1 & 2 & \\
\hline & \multirow{2}{*}{ Ulna } & $\mathrm{HNU}$ & - & 1 & 1 & 2 & \\
\hline & & ANU & 1 & - & - & 1 & \\
\hline & \multirow{3}{*}{ Radius and ulna } & $\mathrm{HNU}$ & 2 & - & 2 & 4 & \\
\hline & & $\mathrm{ANU}$ & 1 & 2 & - & 3 & \\
\hline & & Nonunited fracture & 1 & - & - & 1 & \\
\hline \multicolumn{3}{|l|}{ Total } & $23(27.7 \%)$ & $28(33.8 \%)$ & $32(38.5 \%)$ & $83(1$ & $\%$ \\
\hline
\end{tabular}


Distribution of patients by the type of nonunion amd surgery performed $(n=83)$

\begin{tabular}{|c|c|c|c|c|c|c|c|c|c|c|}
\hline \multirow{3}{*}{ Surgery performed } & \multicolumn{3}{|c|}{ Control group } & \multicolumn{3}{|c|}{ Group I } & \multicolumn{3}{|c|}{ Group II } & \multirow{3}{*}{ Total } \\
\hline & \multicolumn{9}{|c|}{ Type of pathology } & \\
\hline & $\mathrm{HNU}$ & ANU & \begin{tabular}{|c|}
$\begin{array}{c}\text { Nonunited } \\
\text { fracture }\end{array}$ \\
\end{tabular} & $\mathrm{HNU}$ & ANU & $\begin{array}{c}\begin{array}{c}\text { Nonunited } \\
\text { fracture }\end{array} \\
\end{array}$ & $\mathrm{HNU}$ & ANU & $\begin{array}{c}\text { Nonunited } \\
\text { fracture }\end{array}$ & \\
\hline Closed application of the Ilizarov frame & 6 & 6 & 4 & - & - & - & - & - & - & $17(20.7 \%)$ \\
\hline Open IM nailing & 3 & 2 & 1 & - & - & - & - & - & - & $6(6.1 \%)$ \\
\hline Autologous bone grafting and plating & - & - & - & 6 & 14 & 1 & - & - & - & $21(24.4 \%)$ \\
\hline $\begin{array}{l}\text { Bone grafting with the Khakhutov technique } \\
\text { and plating }\end{array}$ & - & 1 & - & 5 & 2 & - & - & - & - & $8(9.7 \%)$ \\
\hline $\begin{array}{l}\text { Ilizarov external fixation and local injection } \\
\text { of kukumazim and autologous bone marrow }\end{array}$ & - & - & - & & & - & 10 & - & 3 & $13(39.7 \%)$ \\
\hline $\begin{array}{l}\text { Ilizarov external fixation, bone osteotomy } \\
\text { and local injection of kukumazim and } \\
\text { autologous bone marrow }\end{array}$ & - & - & - & - & - & - & - & - & 19 & $19(61.3 \%)$ \\
\hline
\end{tabular}

\section{RESULTS}

Control patients (retrospective group) were treated by compression-distraction osteosynthesis with the Ilizarov apparatus $(n=17)$ and intramedullary nailing $(n=6)$ and also received traditional therapy (antibiotic therapy, painkillers, vascular therapy and calcium preparations). Outcomes were rated as good $(\mathrm{n}=14 ; 60.8 \%)$ in the control group at a short term (withing a year after surgery), fair $(\mathrm{n}=5 ; 21.8 \%)$ and poor $(\mathrm{n}=4 ; 17.4 \%)$, and a high rate of poor results initiated the search for other methods of eliminating complicated and debilitating conditions of long bone fractures. Three control patients with ANU out of four had a poor outcome and the surgery failed to address the complication with nonunion, atrophic soft tissues and shortening of the segment of more than $2 \mathrm{~cm}$. A patient (out of 4 ) with a proximal fracture of both forearm bones had a poor result developing contracture of the elbow joint and limited range of motion, synostosis of both forearm bones and absent rotation of the forearm. Patients with a fair result developed contracture of adjacent joints, soft tissue atrophy and ulnar shortening of $2 \mathrm{~cm}$ (in one of five cases). At a longer term, i.e. more than 1 year after surgery, the number of good postoperative results increased by almost $10 \%$ from $60.8 \%$ at oneyear follow-up to $69.5 \%$ after one-year follow-up. Patients with fair results could improve contractures of adjacent joints and soft tissue hypotrophy in the first year after the operation and move to good outcome group. A patient with elbow nonunion whose outcome was rated as poor at a one-year follow-up could progress to a good result group due to repeated surgery. At a long term the number of patients with poor results decreased two-fold, from 4 to 2 cases due to improved tissue atrophy in one patient of this group and reduced shortening of the segment of less than $2 \mathrm{~cm}$ with the result rated as fair. The number of patients with a fair result remained unchanged due to reassessment of surgical outcomes.

Functional results evaluated in the adjacent joints of controls preoperatively, at a short (up to 1 year) and long terms (over 1 year after the operation) showed a $5^{\circ}$ decrease in elbow extension from preoperative $177.2 \pm 0.82^{\circ}$ to $172.2 \pm 1.4^{\circ}$ at a short term (Fig. 1). Dorsiflexion in the radiocarpal joint decreased from preoperative $78.9 \pm 1.7^{\circ}$ to $48.7 \pm 1.2$ at a short term showing a mean flexion reduction of almost $20^{\circ}$. All the parameters demonstrated deterioration from 1.02 to 1.6 times due to prolonged immobilization, restricted range of motion and functions of the involved limb (Fig. 1). However, patient could progress with the measurements to preoperative level with deviation exceeding the preoperative values. The average period of limb immobilization was $135.5 \pm 1.0$ days (range, 127 to 148 days) (Table 3 ).

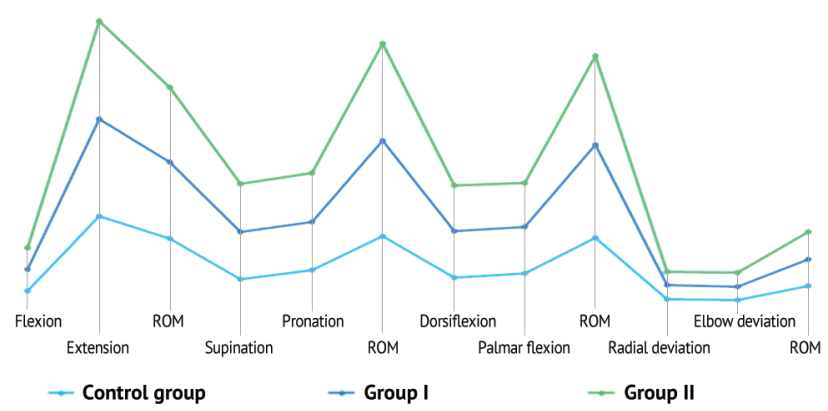

Fig. 1 Functional results of patients with nonunited forearm fractures at a long term

The patients could not develop normal anatomical and functional parameters in the adjacent joints at a long term, and this was another reason to search for new tactical approaches. Clinical assessment of pain, atrophy of soft tissues, shortening of the segment and cosmesis showed low mean scores at a short and long 
terms measuring less than 2 points at a short term, which meant a poor result and less than 3 points at a long term with the differences being significant in half of the evaluated criteria at a short and long term. The same tendency was seen in the radiological parameters for the limb recovery. We also evaluated the extent of recovery of the segment circumference in the involved and normal limb at a short and long term comparing the average difference between the circumferences with the difference being significant proximally and distally, and more than 12 months were required for grafting and plating was performed for 20 patients of group I ( 25 nonunions and 3 nonunited fractures) and bone grafting with the Khakhutov method was produced for 8 patients of group I. Surgical treatment of the patients included bone grafting and plating combined with a single local injection of kukumazim and autologous bone marrow for the nonunions (HNU, ANU) located in the proximal forearm. Postoperative findings showed atrophic nonunion in 14 patients out of 25 , hypertrophic nonunion in 11 cases, and three patients had nonunited fracture of the forearm bones.

Good outcomes were recorded in $22(78.6 \%)$ patients at a short term that increased to $82.1 \%$ $(n=23)$ during the follow-up of more than one year due to patients with fair results who could improve the condition at a longer term. The figure demonstrated the disabling patients who could not use the injured arm. There were four patients with fair results at one year and the number persisted at a longer term followup due to poor outcomes of hypertrophic union moving to the fair group at a long term, and a patient with fair outcome could improve his contracture and soft tissue hypotrophy at a longer term and the result was rated as good. A poor outcome was observed in HNU $(n=1)$ and ANU $(n=1)$ cases who developed rotation, flexion and extension contracture, impaired deviation with soft tissue atrophy at a short term and HNU patients could improve to a fair result due to the circumferences to be identical. Autologous bone

long-term rehabilitation therapy and compliance. The ANU patient's result remained poor at a long term because of the segment shortening of more than $2 \mathrm{~cm}$, severe scars and soft tissue atrophy.

Patients of group I showed very interesting and encouraging functional and clinical results at a long term. The differences in the parameters were observed at one-year follow-up as compared to preoperative measurement, and statistical analysis showed differences in the functionality of the elbow and radiocarpal joints, magnitude of rotation and deviation of the hand with a high degree of confidence $(p<0.001)$ (Fig. 1) at a long term as compared to preoperative anthropometric characteristics, except for the elbow flexion that measured $40.9 \pm 0.8^{\circ}$ preoperatively and $39.6 \pm 0.5^{\circ}$ at a long term. The fact can be ascribed to preoperative normal elbow flexion. Although the deviation at a long term showed significant differences as compared to the preoperative values it did not reach the expected maximum, but only approached the lower threshold of the normal $25-35^{\circ}$ (Marks). Improvements in rotation (from preoperative supination of $70.3 \pm 1.2^{\circ}$ to $86.8 \pm 0.8^{\circ}$ at a long term; from preoperative pronation of $80.1 \pm 1.2^{\circ}$ to $89.3 \pm 0.3^{\circ}$ at a long term; from preoperative ROM of $150.5 \pm 1.9^{\circ}$ to $176.4 \pm 0.8^{\circ}$ at a long term) could demonstrate the efficacy of the technique developed to regain complete motion in the joints of the upper limb. Patients could also regain the arc of motion in the radiocarpal joint (Fig. 1). The mean clinical scores of less than three points could be caused by a poor outcome in a patient who developed shortening of the segment at a long term. A comparison of the mean scores values at a short and long term revealed the significant differences in atrophy of soft tissues: $2.4 \pm 0.15$ points at a short term and $2.85 \pm 0.11$ at a long term. We can conclude that the technique we used can create a favorable environment for the early recovery of soft tissues at the site of injury due to early rehabilitation of the involved limb (Table 3).

Table 3

Results of complex surgical treatment of patients with forearm nonunions and nonunited forearm fractures at a long term

\begin{tabular}{|c|c|c|c|c|}
\hline & \multicolumn{3}{|c|}{ Groups } \\
\hline & & Control group & Group I & Group II \\
\hline \multicolumn{2}{|c|}{ Callosity initiated (days) } & $82.1 \pm 0.63$ & $77.1 \pm 0.67 * * *$ & $73.2 \pm 0.52 * * *$ \\
\hline \multicolumn{2}{|c|}{ Callosity fully formed (days) } & $206.4 \pm 0.66$ & $197.5 \pm 0.48 * * *$ & $192.7 \pm 0.43 * * *$ \\
\hline \multirow{3}{*}{$\begin{array}{l}\text { Restoration of } \\
\text { limb function }\end{array}$} & Elbow ROM, $^{\circ}$ & $136.7 \pm 1.0$ & $139.8 \pm 0.5$ & $138.1 \pm 1.14$ \\
\hline & Elbow ROM, $^{\circ}$ & RCJ. $^{\circ}$ & $170.2 \pm 1.1$ & $164.2 \pm 2.3$ \\
\hline & rotation, $^{\circ}$ & $141.0 \pm 2.4$ & $176.4 \pm 0.8$ & $178.1 \pm 0.6$ \\
\hline \multicolumn{2}{|c|}{ Soft tissue recovery (score) } & $2.43 \pm 0.1$ & $2.85 \pm 0.11^{*}$ & $2.8 \pm 0.09^{* *}$ \\
\hline \multicolumn{2}{|c|}{ Immobilization period (days) } & $135.5 \pm 1.0$ (range, $127-148)$ & $105.1 \pm 1.0(94-112)^{* * *}$ & $104.7 \pm 0.97(96-110) * * *$ \\
\hline
\end{tabular}




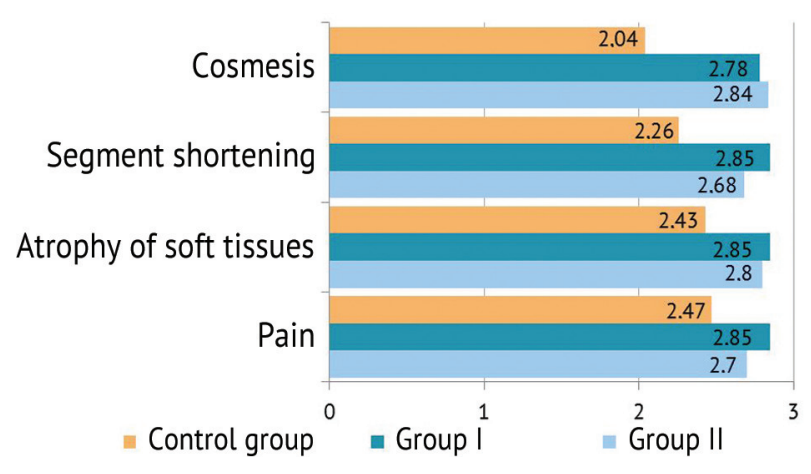

Fig. 2 Clinical results in patients with non-united fractures and nonunions of the forearm bones at a longterm follow-up (scores)

Consolidation of the nonunion and quality of callosity were evaluated radiologically in scores. The average consolidation rate was low and scored $2.46 \pm 0.09$ at a short term, and appeared to be higher at a long term with an average score of $2.96 \pm 0.035$ showing significant differences $(p<0.001)$. The average values of the other radiological criteria evaluating limb alignment and restoration of joints, were close to normal at a short term and improved at a long-term follow-up. The criterion of radiologically confirmed limb shortening at a short term was somewhat behind the values of other criteria due to the fact that, as noted above, one patient had a shortening of more than $2 \mathrm{~cm}$ and showed improvement but scored under three point at a long term. But the positive trend at a long-term follow-up gives hope for bone recovery at a longer term (Fig. 3).

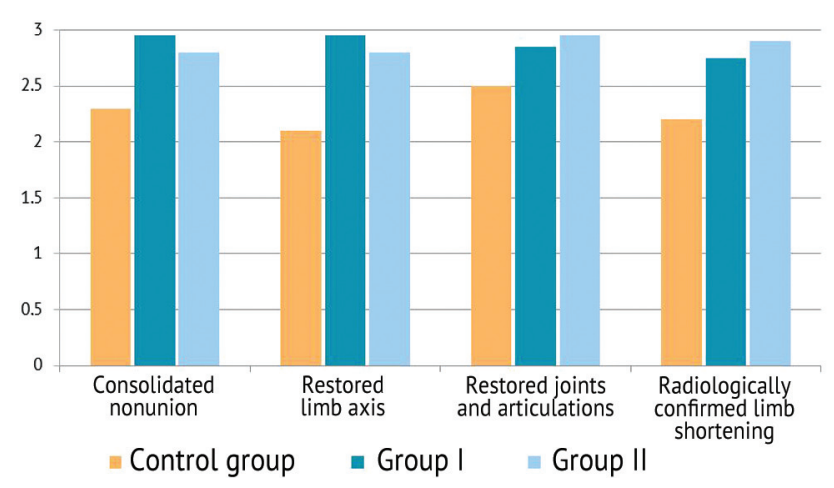

Fig. 3 Radiological criteria in patients with nonunited forearm fractures and forearm nonunions at a long term (score)

The treatment resulted in reduced length of immobilization from $135.5 \pm 1.0$ days in the control group (range, $127-148$ days) to $105.1 \pm 1.0$ days (range, 94-112 days) $(\mathrm{p}<0.001)$ showing a 1.3 times reduction in the period of immobilization considering the mean patients' age, psychological implications with the reduced fixation period of more than a month (Table 3).

The next criterion for assessing the extent of recovery was a segment-by-segment measurement of the difference in the circumferences of the involved and healthy limb with the average difference in circumference in all parts reaching almost $2 \mathrm{~cm}$ at the levels of the forearm bones on average and showing significant soft tissue atrophy. The difference in the circumferences of the involved and healthy limb significantly decreased $(p<0.01)$ at a short term in comparison with the preoperative values. The difference was less significant $(p<0.001)$ at a long term as compared to preoperative measurements, and there was no difference in the circumferences of the involved and healthy limb when evaluating individual measurements due to favorable environment provided for the restoration of soft tissues with the use of the improved technique.

Group II included 32 patients with nonunited fracture or atrophic or hypertrophic nonunions located in the mid shaft or the distal forearm bones. Patients with nonunited forearm fractures or HNU in the middle or lower thirds of the forearm bones $(13 \mathrm{ANU}+3$ nonunited forearm fractures) underwent the Ilizarov external fixation combined with injection of autologous bone marrow and a kukumazim solution. Patients with atrophic nonunion located in the middle and lower thirds were treated with osteotomy, the Ilizarov external fixation and a single injection of autologous bone marrow and a kukumazim solution. Overall, patients of group II $(n=32)$ were diagnosed with hypertrophic nonunion $(\mathrm{n}=13 ; 40.6$ $\%)$, atrophic nonunion $(\mathrm{n}=16 ; 50.0 \%)$ and non-united fracture of forearm bones $(n=3 ; 9.4 \%)$. The patients had an isolated injury to the radius $(\mathrm{n}=11 ; 34.4 \%)$, ulnar injury $(\mathrm{n}=11 ; 34.4 \%)$, and injury to both bones $(\mathrm{n}=10 ; 31.2 \%)$. Outcomes scored 3 for all criteria were rated as good $(n=22 ; 68.7 \%)$ at a short term suggesting that within the first year, the patients could return to their normal style of life with the limb function restored and to work within a year. At a long term, good outcomes numbered $28(87.6 \%)$ cases due to the improved contractures, soft tissue hypotrophy in four patients out of $6(18.8 \%)$ rated as a fair outcome at a short term. Two $(6.2 \%)$ patients retained fair outcome at a long term with soft tissue hypotrophy and joint contractures persisting after 12 months of follow-up. Two ANU patients out of 4 $(12.5 \%)$ cases with poor results at a short term underwent re-operation that led to the results scored 3 and rated as good adding to the good outcome group at a long term. The third ANU patient with a poor quantitative and qualitative assessment of the parameters at a short term demonstrated complete bone consolidation and complete restoration of all limb functions with persistent segment shortening of more than $2 \mathrm{~cm}$ despite bone distraction performed in the catamnesis, and the result was rated as 
fair at a long term. An ANU (3.1\%) case with a poor outcome at a short term retained the poor status at a long term due to contracture, nonunion and soft tissue atrophy. At a long term the patient was offered a re-operation, which he refused.

The average anthropometric ROM in the adjacent joints of the involved limb measured preoperatively and postoperatively showed good dynamics at a long term. Preoperative and postoperative elbow flexion was well within acceptable limits of normal measuring $42.9 \pm 1.36^{\circ}$ and $40.3 \pm 0.67^{\circ},(p>0.05)$, correspondingly. Elbow extension was well within acceptable limits of normal measuring $178.6 \pm 0.56^{\circ}$ at a long term versus preoperative $172.3 \pm 1.3^{\circ}$ $(\mathrm{p}<0.001)$. The elbow ROM significantly improved at a long term measuring $129.4 \pm 2.36^{\circ}$ preoperatively versus $138.1 \pm 1.14^{\circ}$ in the catamnesis $(\mathrm{p}<0.02)$ (Fig. 1). Comparative analysis of rotation, radiocarpal movements and hand deviation showed restoration of all parameters to be well within acceptable limits of normal at a long term with a high degree of reliability $(\mathrm{p}<0.001)$. Best surgical treatment appears to depend on individual patient circumstances with the specific pathologies discussed above in patients of group II.

The average immobilization period was $104.7 \pm 0.97$ (range, 96-110) days in patients of group II versus $135.5 \pm 1.0$ (range, 127-148) days in controls with a high degree of reliability $(\mathrm{p}<0.0001)$ and the average difference of more than 30 days between the groups. This could be achieved due to early rehabilitation and stimulation with a single local injection of kukumazim and autologous bone marrow at the time of surgery (Table 3). We also compared the average clinical parameters of pain, soft tissue atrophy, segment shortening, cosmesis), radiological manifestations criteria, segment circumferences in patients of group II at a short and long term. The mean pain score was shown to be significantly reduced and amounted to $1.4 \pm 0.17$ points at a short term and gradually increased $(\mathrm{p}<0.001)$ at a long term and scored $2.7 \pm 0.11$. The rest clinical parameters were high on average, scored to 3 points in many cases at a short term and improved at a long term but failed to score the mean three due to a poor oucome ( $\mathrm{n}=1)$ (Fig. 2).

The average radiological measurements as the most objective criteria scored more than 2 in most patients of the group $(n=22)$ at a short term with limb functions restored and outcomes of 4 patients of the group were rated as poor. The mean consolidation time and joint restoration scored $2.4 \pm 0.11$ and $2.4 \pm 0.2$, correspondingly. The radiological manifestations of the nonunion site significantly improved after 12 months or more and scored $2.78 \pm 0.1$ for consolidation $(\mathrm{p}<0.05$ with regard to a short-term follow-up) and $2.84 \pm 0.1$ for realigned $\operatorname{limb}(\mathrm{p}>0.05$ with regard to a short-term follow-up). Joint restoration and limb shortening could be radiologically well improved over time.

The dynamics in the average recovery parameters of the segment circumference showed a high degree of reliability in the differences in characteristics $(p<0.001-p<0.0001)$ for each segment in comparison with a healthy limb preoperatively, at a short and long term (Table 3). The difference in the circumference of the proximal forearm was $0.94 \pm 0.06 \mathrm{~cm}$ and $0.29 \pm 0.01 \mathrm{~cm}$ at a short and long term, correspondingly; $1.44 \pm 0.05 \mathrm{~cm}$ and $0.72 \pm 0.01 \mathrm{~cm}$ in the middle third of the forearm, correspondingly, and $1.13 \pm 0.05$ and $0.43 \pm 0.06 \mathrm{~cm}$ in the distal forearm, correspondingly, with a small external difference in both limbs (Table 3). The surgical treatment of ANU located in the middle and lower third of the forearm bones included osteotomy and the Ilizarov external fixation combined with a single local injection of kukumazim and autologous bone marrow. Kukumazim, $50 \mathrm{PE}$, was injected at the site of ANU a day before the surgery to accelerate bone regeneration. On the next day the bone was surgically realigned under general anesthesia in sterile condition with a patient in supine position using the Ilizarov external fixation applied to stabilize and lengthen the bone. With the osteotomy produced proximally the bone was daily distracted at the rate of 1-2 mm per day until the defect was completely eliminated. Distraction was performed for 2-6 weeks depending on the size of the defect and callosity was radiologically identified meanwhile. A $2 \mathrm{~mL}$ autologous bone marrow was injected at the NU site, an aseptic bandage applied to the involved area, the Ilizarov pin sites and at the injection site. The Ilizarov frame was on until complete bone consolidation.

Case report Patient Kh., born 1965, was admitted on 28.03.2012 and discharged from the hospital on 06.04.2012. She was diagnosed with nonunion in the middle third of the right ulna and a bone defect, united fracture in the upper third of the right radius. She was originally treated with IM nailing and the Ilizarov external fixation in the city hospital of Dzhambul, Kazakhstan in September 2011 , one year before admission to our hospital. The Ilizarov frame was dismantled two months later and a plaster cast applied. With the above complaints, the patient was hospitalized in our clinic. Her physical examination showed a large skin defect and rough scars at the NU site. General endotracheal 
anesthesia was produced with i/v Sol. Sibazoni $0.5 \%-2.0 \mathrm{~mL}$, Sol. Promedoli $2 \%-1.0 \mathrm{~mL}$, Sol. Ketamini $5 \%-3.0 \mathrm{~mL}$. To maintain anesthesia: i/v Sol. Droperidoli $0.25 \%-6.0 \mathrm{~mL}$, Sol. Phentanyli $0.005 \%-10.0 \mathrm{~mL}$, Sol. Ketamini $5 \%-7.0 \mathrm{~mL}$. Intraoperatively: Sol. Glucosae $5 \%-400.0 \mathrm{~mL}$, Sol. $\mathrm{NaCl} 0.9 \%$ - $400.0 \mathrm{~mL}$. Preoperative common urine test: $\mathrm{Hb}-100 \mathrm{~g} / \mathrm{L} ; \mathrm{RBC}-3.4 \times 10^{12} / \mathrm{L} ; \mathrm{WBC}-$ $6.8 \times 10^{9} / \mathrm{L} ; \mathrm{ESR}-5 \mathrm{~mm} / \mathrm{h}$; segment. nucl. $-59 \%$, rod nucl. $2 \%$; eos. $-1 \%$, lymph. $-32 \%$, mon. $6 \%$; common urine test on the $2^{\text {nd }}$ day after surgery: $\mathrm{Hb}-96 \mathrm{~g} / \mathrm{L} ; \mathrm{RBC}-3.3 \times 10^{12} / \mathrm{L}$; c.p. -0.9 ; WBC $6.9 \times 10^{9} / \mathrm{L} ; \quad$ ESR $-15 \mathrm{~mm} / \mathrm{h} ;$ segment. nucl$47 \%$, rod nucl. $-2 \%$; eos. $-3 \%$, lymph. $-41 \%$, mon. $-7 \%$.

Surgical procedure performed on 30.03.2012 included osteotomy of the upper third of the right ulna, application of the Ilizarov external fixator (Fig. $4 \mathrm{~b})$ with $50 \mathrm{PE}$ kukumazim injected at the site of ANU a day before the surgery and $3 \mathrm{~mL}$ autologous bone marrow harvested from the iliac crest was injected intraoperatively at the NU site. Ulna was osteotomized proximally to repair the defect, and the bone was daily distracted at the rate of $1 \mathrm{~mm}$ per day in proximal-to-distal direction. Control radiography was performed after 2 months and the Ilizarov frame was dismantled. A radiograph (Fig. 4d) showed the newly formed distractional callus with proper time given to the bone to consolidate. Patient Kh. was readmitted to the hospital to have nonunion repaired on 06.11.2012 and Ilizarov external fixation of the right forearm bones was produced on 07.11.2012 with kukumazim injected at the site of ANU a day before the surgery and autologous bone marrow introduced intraoperatively (Fig. 4e). The Ilizarov apparatus was dismantled at 2.5 months with the callosity visualized on check-up X-ray, the wounds healed by primary intention (Fig. 4f). The patient Kh. showed good recovery of clinical, functional and radiological parameters with the outcome rated as good (Fig. 4g).

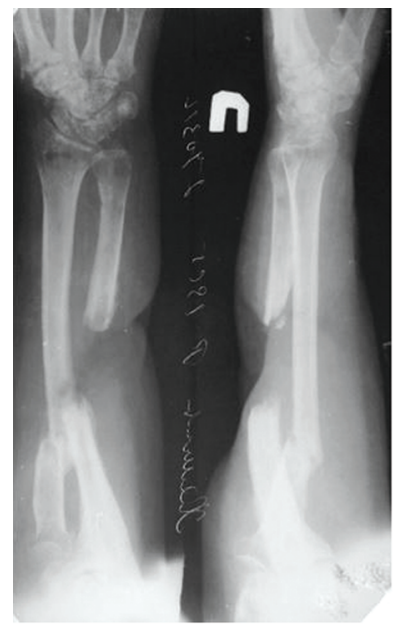

a

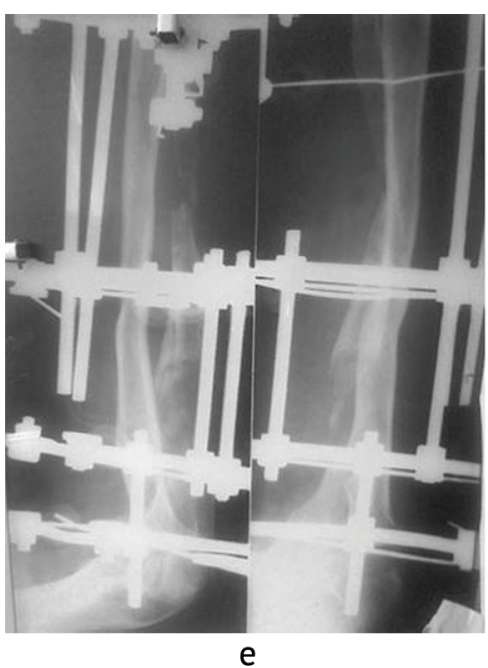

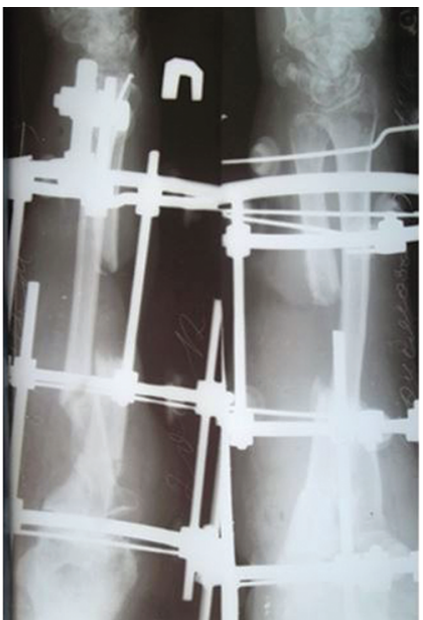

b

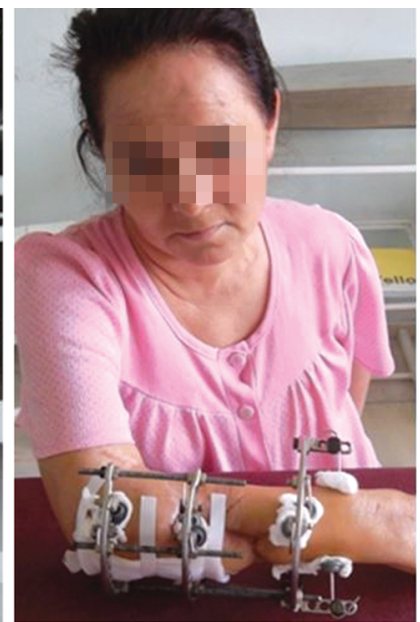

C

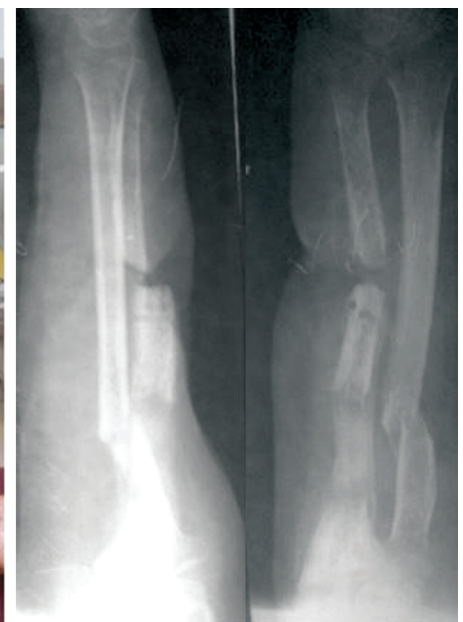

d
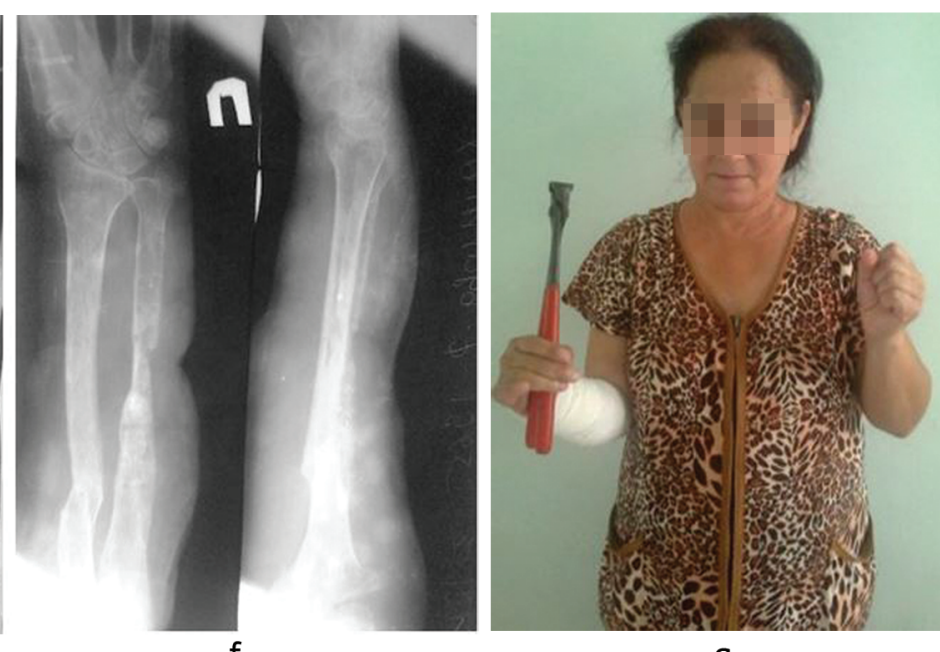

g

Fig. 4 Patient Kh.: $(\boldsymbol{a})$ preoperative radiograph showing nonunion in the mid shaft of the right forearm and a bone loss; (b) radiographs showing the Ilizarov external fixation of the forearm bones; $(\boldsymbol{c})$ clinical appearance of the patient with external fixator on; $(\boldsymbol{d})$ radiographs at 2.5 months following the Iliarov frame removal; $(\boldsymbol{e})$ radiographs with Ilizarov frame on re-applied; $(f)$ radiographs showing nonunion consolidation; $(\mathrm{g})$ clinical appearance of the patient showing her functions regained 


\section{DISCUSSION}

A variety of surgical methods have been developed for the treatment of nonunited forearm bone fractures and nonunions with the use of bone grafting and different fixation devices. Auto- and allografts were reported to be effective in the treatment of forearm nonunions and bone defects $[7-11,13,15]$, and grafting was shown to be associated with complex processes of bone resorption and restructuring that occurr simultaneously and require long-term and stable fixation. Bone grafting is reported to be indicated for nonunions and severe sclerosis, closed bone marrow canal and marginal bone defects [7, $9,11,20]$; for isolated stiff forearm nonunions or after intramedullary nailing [1, 3, 18, 20]. Unstable osteosynthesis or insufficiently prolonged forearm immobilization with a plaster cast were reported as major causes of failed bone grafting [21, 22]. Optimal environmant was believed to be crucial for the transplanted graft $[9,14,15,8,23,24]$. Circular or petal-like bone - periosteal decortication can be used with less injury to the vessels running from the periosteum into the cortical bone of the maternal bed contributing to better revascularization of the grafts $[17,25]$. Microsurgical techniques allowed transplantation of tubed autografts on the vascular pedicle, but vascular anastomoses procedures are prolonged and have high risk of complications [12]. In addition, such operations require special surgical expertise and appropriate equipment. Althought wires [1], half-pins and nails $[18,20]$ are used for intraosseous fixation of the broken forearm bones they can fail to provide sufficient bone stability in some cases. Ling HT et al. [19] reported the use of mass intraosseous nails contributing to the rapid bone consolidation. However, pre-drilling of the intramedullary canal significantly interferes with endosteal blood circulation and reparative osteogenesis [3]. Re-alignment of the physiological curvature of the forearm bones is associated with restricted rotation. The frequent migration of intramedullary fixators is reported by some authors $[3,18]$.
Although bone metal plates, compression plates can ensure strong bone fixation and early functional loading [16] re-fracture can often occur as a debilitating condition due to the weakening of bone tissue with the formation of transcortical channels [17, 19, 25]. Some authors [26, 27] prefer compression bone plating. Tauber C. and Pritsch M. [5] reported no stimulating effect on regeneration with bone compression; other researchers [4] recommended the use of dynamic compression of bone fragments. A significant rate of poor outcomes (from 12 to $71 \%$ ) was reported to be associated with unstable fixation, lack of a differentiated approach to a particular method of treatment $[2,6,28,29]$. Some researchers support stable osteosynthesis as the necessary factor for the consolidation of the forearm bones $[7,15,30]$. Compression-distraction methods of treatment with an external fixation device have received significant recognition in orthopedic and trauma practice. More than 100 devices have been developed to include wires, half-pins and hybrid wire-and-half-pins. Closed reduction of the four displaced forearm fragments is a challenging procedure. Complications being associated with the use of compression-distraction devices include pin tract infection, neurovascular disorders, osteomyelitis at the pin sites, etc. are reported to occur in $27-33 \%[31,32]$. Some authors $[30,33]$ suggest that compression-distraction devices are not efficient for the treatment of nonunited forearm fractures and nonunions.

Puseva M. E. et al. [34] reported the creation of normal anatomical relationships in the radioulnar joints as the necessary condition for restoration of the forearm function to be achieved using the IM rodding with the radial head reduced and the annular ligament repaired [34]. Ulnar pre-distraction of fragments with an external fixation device can be recommended to be followed by IM nailing [31]. Resection of the radial head can be suggested for long-standing Monteggia fractures [34] with the use of the resected radial head for stimulation of osteogenesis at the ulna nonunion.

\section{CONCLUSION}

1. Treatment of patients with forearm nonunions located in the middle and lower thirds with Ilizarov external fixation and local osteostimulation with the introduction of kukumazim and autologous bone marrow contributed to a significant $(p<0.001)$ reduction in the immobilization duration of $105.1 \pm 1.0$ days (compared with the control group).
Treatment of patients with forearm nonunion located in the upper third with autografting and plating combined with local osteostimulation using kukumazim and autologous bone marrow resulted in a significant $(p<0.001)$ reduction of the immobilization period to an average of $104.7 \pm 0.97$ days as compared to the controls (135.5 \pm 1.0 days). 
2. Complete clinical and anatomical restoration of limb functions was observed in $82.1 \%$ of cases of group I and in $87.6 \%$ of group II at a long term.

3. Optimization of surgical treatments and considerations for injury pattern and localization allowed for a 2.8 -time $(3.1 \%)$ decrease in poor outcomes and a $30 \%$ reduction in the limb immobilization period.

\section{REFERENCES}

1. Barabash A.P., Barabash Iu.A. Intramedulliarnaia sistema fiksatsii Fixion v lechenii perelomov, lozhnykh sustavov dlinnykh kostei [Fixion intramedullary fixation system in treatment of fractures, pseudoarthroses of long bones]. Genij Ortopedii, 2010, no. 2, pp. 44-49. (in Russian)

2. Dmitriev A.E., Ivannikov S.V., Ianovskaia E.M. Otsenka rezultatov lecheniia lozhnykh sustavov kostei predplechia, osnovannaia na analize dannykh radionuklidnykh issledovanii [The evaluation of the results of treatment of pseudoarthroses of the forearm bones based on the analysis of radionuclide study data]. Khirurgiia, 1991, no. 12, pp. 48-50. (in Russian)

3. Badawi I. Combined intramedullary and extramedullary fixation with autogenous bone grafting for the treatment of forearm nonunions with severe bone loss. The Egyptian Orthopaedic Journal, 2017, vol. 52, no. 4, pp. 251. DOI: 10.4103/eoj.eoj_69_17

4. Kenan M.A., Habib H.R. Diaphyseal Fracture-Nonunion of Forearm Bone Treated by Compression Plating Aided with Autologous Bone Grafting - A Study Outcome. J. Orthop. Clin. Stu. Adv. Res., 2018, vol. 2, no. 1. DOI: 10.16966/2576-6449.106

5. Tauber C., Pritsch M. Non-union of forearm fractures with reference to plate osteosynthesis. Orthop. Rev., 1980, vol. 9, pp. 80-91.

6. Ibragimov S.Kh. Kriterii otsenki anatomo-funktsionalnogo sostoianiia verkhnei konechnosti u bolnykh i invalidov s posledstviiami perelomov kostei predplechia. Diss. ... kand. med. nauk [The criteria of evaluation of anatomic-and-functional condition of the upper limb in patients and disabled persons with the consequences of the forearm bone fractures. Cand. med. sci. diss.]. Tashkent, 2000, 123 p. (in Russian)

7. Sokolova M.N. Lechenie bolnykh s defektami i lozhnymi sustavami kostei predplechia metodom chreskostnogo osteosinteza. Avtoref. diss. ... kand. med. nauk [Treatment of patients with defects and pseudoarthroses of the forearm bones by the method of transosseous osteosynthesis. Cand. med. sci. diss. abstr.]. Kurgan, 2011, 24 p. (in Russian)

8. Tsuman V.G., Mashkov A.E. Autotransplantatsiia kostnogo mozga pri lechenii lozhnykh sustavov i obshirnykh defektov trubchatykh kostei [Bone marrow autografting in treatment of pseudoarthroses and extensive defects of long bones]. Detskaia Khirurgiia, 2006, no. 2, pp. 14-17. (in Russian)

9. Borzunov D.Y. Nesvobodnaia kostnaia plastika po G.A. Ilizarovu v probleme reabilitatsii bolnykh s defektami i lozhnymi sustavami dlinnykh kostei [Non-free bone grafting according to G.A. Ilizarov in the problem of rehabilitation of patients with long bone defects and pseudoarthroses]. Genij Ortopedii, 2011, no. 2, pp. 21-26. (in Russian)

10.Goldman B.M., Litvinova N.A. Osteosintez kompressiruiushchimi metallicheskimi plastinami pri svezhikh i nesrosshikhsia perelomakh, lozhnykh sustavakh i defektakh kostei predplechia [Osteosynthesis with compressing metal plates for fresh and nonunited fractures, pseudoarthroses and defects of the forearm bones]. Vestnik Khirurgii, 1981, no. 5, pp. 113-117. (in Russian)

11.Gubochkin N.G., Mikitiuk S.I., Ivanov V.S. Peresadka krovosnabzhaemykh kostnykh transplantatov dlia lecheniia lozhnykh sustavov i defektov kostei [Transplantation of vascularized bone grafts for treatment of bone pseudoarthroses and defects]. Genij Ortopedii, 2014, no. 4, pp. 5-10. (in Russian)

12.Dazhin A.Iu., Minasov B.Sh., Valeev M.M., Chistichenko S.A., Biktasheva E.M. Svobodnaia kostnaia plastika vaskuliarizirovannym fragmentom malobertsovoi kosti pri lechenii bolnykh s obshirnymi segmentarnymi defektami kostei predplechia [Free osteoplastee osteoplasty using a vascularized fibular fragment for treatment of patients with extensive segmental defects of forearm bones]. Geniij Ortopedii, 2013, no. 2, pp. 58-61. (in Russian)

13.Zaks Kh.O., Avanesov R.R. Osteosintez plastinami diafizarnykh nesrosshikhsia perelomov i lozhnykh sustavov kostei predplechia [Osteosynthesis of shaft non-united fractures and pseudoarthroses of the forearm bones using plates]. Resp. sb. nauch. trudov "Aktualnye voprosy lecheniia povrezhdenii i zabolevanii oporno-dvigatelnoi sistemy" [Republican Proceedings "Relevant Problems of the Treatment of Injuries and Diseases of the Locomotor System”]. Vladimirskii MONIKI, Moscow, 1990, pp. 89-91. (in Russian)

14.Krylov A.A. Lechenie lozhnykh sustavov kostei predplechia s primeneniem ekstraossalnogo fiksatora [Treatment of pseudoathroses of the forearm bones using an extra-osseous fixator]. Ortopediia, Travmatologiia i Protezirovanie, 1977, no. 5, pp. 81-83. (in Russian)

15.Makazhanov O.Kh. Autoplasticheskii sposob operativnogo lecheniia lozhnykh sustavov diafizov dlinnykh trubchatykh kostei. Avtoref. diss. ... kand. med. nauk [Autoplastic variant of surgical treatment of pseudoarthroses of long tubular bone shafts. Cand. med. sci. diss. abstr.]. Karaganda,1974, 23 p. (in Russian)

16.Faldini C., Pagkrati S., Nanni M., Menachem S., Giannini S. Aseptic forearm nonunions treated by plate and opposite fibula autograft strut. Clin. Orthop. Relat. Res., 2009, vol. 467, no. 8, pp. 2125-2134. DOI: 10.1007/s11999-009-0827-5

17.Dos Reis F.B., Faloppa F., Fernandes H.J., Albertoni W.M., Stahel P.F. Outcome of diaphyseal forearm fracture-nonunions treated by autologous bone grafting and compression plating. Ann. Surg. Innov. Res., 2009, vol. 3, pp. 5. DOI: 10.1186/1750-1164-3-5

18.Hong G., Cong-Feng L., Hui-Peng S., Cun-Yi F., Bing-Fang Z. Treatment of diaphyseal forearm nonunions with interlocking intramedullary nails. Clin. Orthop. Relat. Res., 2006, vol. 450, pp. 186-192. DOI: 10.1097/01.blo.0000214444.87645.75

19.Ling H.T., Kwan M.K., Chua Y.P., Deepak A.S., Ahmad T.S. Locking compression plate: a treatment option for diaphyseal nonunion of radius or ulna. Med. J. Malaysia, 2006, vol. 61, no. Suppl. B, pp. 8-12.

20.Popkov A.V., Popkov D.A., Grebeniuk E.B., Muradisinov S.O. Udlinenie predplechia s napriazhennym intramedulliarnym armirovaniem [Forearm lengthening with stressed intramedullary reinforcement]. Genij Ortopedii, 2007, no. 1, pp. 85-89. (in Russian)

21.Gupta D.K., Kumar G. Gap nonunion of forearm bones treated by modified Nicoll's technique. Indian J. Orthop., 2010, vol. 44, no. 1, pp. 84-88. DOI: 10.4103/0019-5413.58611

22.Kamrani R.S., Mehrpour S.R., Sorbi R., Aghamirsalim M., Farhadi L. Treatment of nonunion of the forearm bones with posterior interosseous bone flap. J. Orthop. Sci., 2013, vol. 18, no. 4, pp. 563-568. DOI: 10.1007/s00776-013-0395-0

23. Chantelot C., Feugas C., Schoofs M., Leps P., Fontaine C. Massive bone loss of the forearm skeleton in trauma victims: six reconstructions with a free fibular transfer. Orthopaedic Proceedings, 2018, vol. 86-B, no. Suppl. 1. Société Française de Chirurgie Orthopédique et Traumatologie. 
24.Crow S.A., Chen L., Lee J.H., Rosenwasser M.P. Vascularized bone grafting from the base of the second metacarpal for persistent distal radius nonunion: a case report. J. Orthop. Trauma, 2005, vol. 19, no. 7, pp. 483-486. DOI: 10.1097/01.bot.0000145970.56642.5b

25.Gupta S., Malhotra A., Mittal N., Garg S.K., Jindal R., Kansay R. The management of infected nonunion of tibia with a segmental defect using simultaneous fixation with a monorail fixator and a locked plate. Bone Joint J., 2018, vol. 100-B, no. 8, pp. $1094-1099$. DOI: 10.1302/0301-620X.100B8.BJJ-2017-1442.R1

26.Kloen P., Buijze G.A., Ring D. Management of forearm nonunions: current concepts. Strategies Trauma Limb Reconstr., 2012 , vol. 7, no. 1, pp. 1-11. DOI: $10.1007 / \mathrm{s} 11751-011-0125-0$

27.Tarallo L., Mugnai R., Adani R., Catani F. Treatment of the ulna non-unions using dynamic compression plate fixation, iliac bone grafting and autologous platelet concentrate. Eur. J. Orthop. Surg. Traumatol., 2012, vol. 22, no. 8, pp. 681-687. DOI: 10.1007/ s00590-011-0902-y

28.Lyzhin A.V. Khirurgicheskoe lechenie psevdoartrozov kostei predplechia. Avtoref. diss. ... kand. med. nauk [Surgical treatment of pseudoarthroses of the forearm bones. Cand. med. sci. diss. abstr.]. Cheliabinsk, 1971, 18 p. (in Russian)

29. Shodiev B.U. Lechenie nesrosshikhsia perelomov i lozhnykh sustavov kostei predplechia [Treatment of non-united fractures and pseudoarthroses of the forearm bones]. Materialy mezhdunar. nauch.-prakt. konf. "Sovremennye Problemy v Travmatologii $i$ Ortopedii" [Proceedings of the International Scientific-Practical Conference "Present Problems in Traumatology and Orthopaedics"]. Travmatologiia zhene Ortopediia, 2008, no. 2 (14), pp. 216. (in Russian)

30.Kuftyrev L.M., Borodin V.V. Rezultaty lecheniia psevdoartrozov kostei predplechia po Ilizarovu [Results of the treatment of pseudoarthroses of the forearm bones according to Ilizarov]. Sbornik nauchnykh trudov "Chreskostnyi kompressionno-distraktsionnyi osteosintez po Ilizarovu $v$ travmatologii $i$ ortopedii" [Proceedings of the Conference "Transosseous Compression-Distraction Osteosynthesis in Traumatology and Orthopaedics"]. Kurgan, 1985, issue 10, pp. 30-33. (in Russian)

31.Zedgenidze I.V. Matematicheskoe modelirovanie komponovok sterzhnevykh apparatov vneshnei fiksatsii [The mathematical modeling of the configurations of rod external fixators]. Genij Ortopedii, 2008, no. 4, pp. 114-117. (in Russian)

32.Tkachenko S.S., Taidukov V.M. Kompressionnyi osteosintez pri lechenii lozhnykh sustavov kostei predplechia [Compression osteosynthesis in the treatment of pseudoarthroses of the forearm bones]. Ortopediia, Travmatologiia i Protezirovanie, 1984, no. 2 , pp. 16-20. (in Russian)

33.Kim A.P. Khirurgicheskoe lechenie nesrosshikhsia perelomov i lozhnykh sustavov proksimalnykh otdelov kostei predplechia. Diss. ... kand. med. nauk [Surgical treatment of non-united fractures and pseudoarthroses of the proximal forearm bones. Cand. med. sci. diss.]. Tashkent, 1993, 160 p. (in Russian)

34.Puseva M.E., Mikhailov I.N., Sidorova G.V. Chreskostnyi osteosintez povrezhdenii Montedzhia [Transosseous osteosynthesis of Monteggia injuries]. Genij Ortopedii, 2009, no. 4, pp. 99-103. (in Russian)

35.Miliukov V.E., Zharikova T.S. Kriterii formirovaniia vozrastnykh grupp patsientov v meditsinskikh issledovaniiakh [Criteria for formation of age-related groups of patients in medical studies]. Klinicheskaia Meditsina, 2015, no. 11, pp. 5-11. (in Russian)

Received: 05.11.2020

Information about the authors:

1. Iskandar Yu. Khodjanov, M.D., Ph.D., Professor, Republican Specialized Scientific-practical Medial Centre of Traumatology and Orthopaedics, Tashkent, Uzbekistan

2. Anvar M. Rakhimov, M.D., Ph.D., Republican Specialized Scientific-practical Medial Centre of Traumatology and Orthopaedics, Tashkent, Uzbekistan, Email: anvar1986-2006@mail.ru

3. Azam A. Kosimov, M.D., Ph.D.,

Tashkent Medical Academy, Tashkent, Uzbekistan,

Tashkent state dental medical Institute, Tashkent, Uzbekistan,

Email: azamrefracture@mail.ru 